Okajimas Fol. anat. jap., 45: 51-69, 1968

\title{
A New Opinion on the Origin of Hassall's Corpuscles
}

\author{
By \\ Masatake Imai, Taizo Shibata and Takao Mineda \\ Department of Anatomy, School of Dentistry, Aichi-Gakuin University \\ Chikusa-ku, Nagoya, Japan
}

A large number of investigators studied on the origin of Hassall's corpuscles, but their opinions would differ from one another.

1) A r nold (1831), $\mathrm{Kr}$ a use (1876), Toldt (1877), K öllike r (1879), H is (1880), Stieda (1881), M a u rer (1886), Orth (1888), Hertwig, O. (1890), C a pobianco (1890), Gontscharukow (1895), R e naut (1897), K a sarinow (1899), Nus b u u and Prymak (1901), Szymonovicz (1901), v. Ebner (1902), Letulle and Nattan-Larrier (1902), Goodall (1905), Gurwitsch (1907), P i e r s o l (1909), M a r in e (1915), O k a m u r o (1928), M i z o$\mathrm{g} \mathrm{u} \mathrm{c} \mathrm{h} \mathrm{i} \mathrm{(1930)} \mathrm{and} \mathrm{T} \mathrm{o} \mathrm{b} \mathrm{a} \mathrm{r} \mathrm{i} \mathrm{(1938)} \mathrm{considered} \mathrm{that} \mathrm{Hassall's} \mathrm{corpuscles}$ originated in the primordial epithelium of the rudiment of the thymus.

2) W i n i w a r te r (1923) concluded that those corpuscles mostly originated in the epithelium, but that there was no denying the participation of the connective tissue.

3) J o lly and Le vin (1910) reported that the same corpuscles in birds arose from the epithelial masses in the medulla of the thymus.

4) Depending on the tissue culture of the thymus, Tschass ow n i k w (1926) held the epithelial origin of Hassall's corpuscles.

5) Bruch (1885), Friedleben (1858), Ma urer (1899), Magni (1903), Tourneux (1909) and Fulci (1913) concluded that the above mentioned corpuscles originated in the epithelial small thymic cells.

6) Dustin (1908) considered that the connective tissue cells, wandering into the thymus from outside, would become the first origin of Hassall's corpuscles.

7) Dahms (1887), Amman (1882), C a p obia nco (1890), His (1880), Ma urer (1899), G hika (1901), Magni (1903) and 
G o l d n e r (1923) held the opinion that the lymphocytes in the thymus had some connection with the origin of those corpuscles.

8) Paulitzky (1863), Watney $(1878,1882)$ and $\mathrm{Amm}$ a $\mathrm{m}$ (1882) had the same view as of $\mathrm{D}$ a h m s', etc., but they considered that the mesenchymal reticular cells also participated in the formation of Hassall's corpuscles.

9) $\mathrm{B} \mathrm{e} \mathrm{c} \mathrm{l} \mathrm{è} \mathrm{r} \mathrm{e-P} \mathrm{i} \mathrm{g} \mathrm{a} \mathrm{ch} e$ (1911) and $\mathrm{P}$ i g a c h e-W or m s (1912) stated that big uninuclear cells and concentric layers of the degenerated leucocytes around them formed Hassall's corpuscles.

10) B e a r d (1902) concluded that Hassall's corpuscles were degenerated parathyroids in the thymus.

11) P o p off (1927) said that Hassall's corpuscles were the degenerated rudimentary organs of the genital and follicular cells.

12) The contention that those corpuscles arose from the degenerated small blood vessels in the thymus was made by Cornil and $R$ anvier (1869), Afanassiew (1877), $\mathrm{Nusbaum}$ and M a chowski (1902), Pflücke (1906), Pry mak and Dustin (1909) and J orda $\mathrm{n}$ and $\mathrm{H}$ ors le y (1927).

13) $\mathrm{Ju} \mathrm{b}$ a and Mi hálik (1929) denied the opinion of J or d a $\mathrm{n}$ and $\mathrm{H}$ or sle y.

14) Jordan and Looper (1928) observed the box-turtle's thymus and corrected the opinion that Hassall's corpuscles originated in the blood vessels.

15) According to $\mathrm{K}$ os to w i e c ki (1930), there was another type of concentric bodies in addition to Hassall's corpuscles derived from the reticulum cells, and they contained degenerated blood vessels in their centers. It was also reported that the degenerated blood vessels were surrounded by the hypertrophied reticulum cells.

16) Prenant (1894), H a m m a r (1905), B ell (1906), P f l ü c ke (1906), S töh r (1906), Mieten s (1908), M a x i m o w (1909), J a f e and Plavska (1925), J u ba and Mihálik (1929), and Smith (1964) contended that the same corpuscles arose from the derivative of the epithelial reticulum in the thymus.

17) Tartozzi (1906) maintained the origin in the mesenchymal reticulum.

18) G r ég o i r e (1932) stated that Hassall's corpuscles were derived from the reticulum cells, and that those cells were originated from the pericytes of the capillaries.

19) S c h a m b a c her (1903) considered Hassall's corpuscles were the concentric substances enveloping the epithelium in the thymusducts. 
20) Putting a cat under the X-ray, R e g a ud and C r é mie u (1910) investigated the change in Hassall's corpuscles and concluded that those corpuscles arose from the reticular cells. But they did not make any comment on those cells whether they were epithelial or mesenchymal.

21) According to G o l d n e r (1923), the reticular cells and unicellular Hassall's corpuscles played the part in the formation of Hassall's corpuscle, and those cells and the unicellular and multicellular Hassall's corpuscles were the degenerative form of the epithelial cells.

22) Ha m mar (1950), Dearth (1928), and $\mathrm{J} \mathrm{u} \mathrm{ba} \mathrm{and} \mathrm{M} \mathrm{i} \mathrm{hálik}$ (1929) considered that the beginnings of the formation of Hassall's corpuscles were the concentric arrangement of the reticulum cells in the medulla around a big cell which was outstanding for its hypertrophied cell body.

23) The hypertrophied reticulum cells having fibrous cytoplasm were described as the unicellular corpuscles of Hassall ( $\mathrm{J}$ or d a $\mathrm{n}$ and

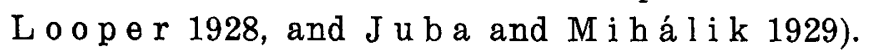

The present authors investigated on Hassall's corpuscles in man and many kinds of animals, re-examined on the opinions of the above mentioned investigators, and have reached a new conclusion.

\section{Materials and Methods}

The materials for this study are as follows.

One toad, Bufo bufo japonicus (SCHLEGEL), four bullfrogs, Rana catesbeiana (SHAw), one striped snake, Elaphe quadrivirgata (BOIE), two grass snake, Rhabdophis tigriuus tigriuus (BOIE), eleven turtles, namely, one Clemmys mutica (CANTOR), six Clemmys japonica (TEMMINCK et SCHLEGEL), four Geoclemys reevesii (GRAY), three softshelled turtle, Trionyx sinensis japonicus (TEMMINCK et SCHLEGEL), one adult fowl of about one year after hatching, each two chickens of ten, twenty, thirty and eighty days after hatching, two adult mice, four adult rabbits, each two rabbit embryos of estimated age twelve, eighteen, twenty and twenty-five days, three one-day-, four sevenday-, and four eleven-day-old rabbits, three four-day and two twentyday kittens, four adult dogs and one puppy, two adult horses, each one cattle of estimated age one year and between two- and threeyears, one calf of a few days, one cattle embryo of the last stage, four Japanese monkeys, Macaca fuscata yakui and one human embryo of estimated age seven months.

The materials were taken in as fresh a state as possible. Some 
of them were fixed in buffered formalin and the others in Carnoy's fluid. All tissues and rabbit embryos were embedded in paraffin, cut in $6 \mu$ thick sections and stained with hematoxylin (Mayer) and eosin. It is to be remarked that the rabbit embryos were cut in series. Feulgen reaction and Unna-Pappenheim's method were used to pursue the degeneration in the myoid cells and the reticular cells around them. To distinguish the epithelial reticular cells from the mesenchymal, Unna's method of water blue-orcein-eosin and Pasini's method were used. Moreover, some sections were stained by van Gieson's method for the myoid cells and epithelial elements. For the electron microscopic studies, the thymus of the Clemmys mutica (CANTOR) was fixed in osmic acid-sucrose and embedded in epon 812.

\section{Observations}

Man and mammals

As the present authors do not see the need of the individual description on their materials, they describe here on something in common in man and some kinds of mammals.

Many or few remarkably big cells are found in the medulla of the thymus in man and all of the above mentioned mammals. For example, the size of the cells in man, cattle and dog is about $18 \mu$, the Japanese monkey is about $14 \mu$ and the rabbit is about $20 \mu$ (Figs. $1,2,7,9)$.

We consider that such cells are the so-called myoid cells. While, they contain no myofibrils in their cytoplasm but many concentric filaments. They have no fibrous processes but the authors found a few cells having short ones in the rabbit (Fig. 8). Nucleusless cells frequently exist in the sections (Fig. 13) but they are nothing but a part of the giant cells in the medulla. Many investigators also have observed these cells in many kinds of animals but their opinions on those cells are different from the present authors', and they will discuss this point later.

When the giant cell, namely the myoid cell, begins the degeneration, a reticular cell will first appear in contact with clear crescent outlines (Figs. 3, 11, 15). It is to be stated that the normal giant cell is not accompanied by such a crescent reticular cell. More degeneration of the giant cell brings with it concentric arrangement of the crescent reticular cells.

The sign of the degeneration in the giant cell is recognizable in the nucleus; in other words, the chromatin is coagulated in big and 
small droplets and they are darkly stained with hematoxylin. The droplets will get into the cytoplasm later (Fig. 5). The decrease of DNA and RNA in the giant cell is observed by Feulgen technique and Unna-Pappenheim's method as the degeneration proceeds (Figs. $6,10)$.

\section{Frog and snake}

Previous investigators already described on the myoid cells in the frog and snake. We also could observe those cells, but they were few in number and contained the concentric myofibrils in their cytoplasm. We frequently find the degenerated myoid cells, but the concentric Hassall's corpuscles are not formed in those animals.

Fowl and turtle

Full investigations on the myoid cells in the fowl have been made by the previous scholars. Through our research, however, the intermediate and middle disks were not clearly observed on the optical microscope. The authors observed the beginning of the concentric Hassall's corpuscle containing the same cell in the center of the corpuscle (Fig. 11).

There are many striated muscles in the medulla of the thymus in the soft-shelled turtle and turtle (Fig. 12). The muscle is peculiarly shaped, and it is with short and long fibers projecting from both sides of the distinct swell in the middle (Fig. 13). Many nuclei are contained in the swell and eight nuclei were found by the authors in a section of a swell. The nuclei are also found here and there in the muscle fiber (Fig. 14). The fibre has the isotropic, anisotropic, intermediate, middle and Hensen's disks (Fig. 16). But Cohnheim's fields in the skeletal striated muscle, or the radiate arrangement of the myofibrils (Fig. 14), the lateral branches of the muscle fibers and intercalated disks which are like those in the cardiac muscles are not found in this muscle (Fig. 12). The myofibrils some time take concentric arrangement in the swell, while many filaments make concentric circles in that place without any muscle fibrils. We can conjecture, therefore, that the myofibrils are contained mixed with the filaments in the swell. The same phenomena are also seen in the fowl. The authors consider that this is to be named as the third striated muscle to the cardiac and skeletal striated muscles.

No new view on this study was obtained by the electron microscopy. 


\section{Discussion}

The present authors have described various contentions of many previous investigators on the origin of Hassall's corpuscles in the introduction. We wish to point out, however, that most of them are far from the reality. The opinion that some cells of the epithelial stroma in the medulla develop into Hassall's corpuscles is supported by many investigators, and this contention presents the control on this problem. Recently, S m ith (1964) also presented this opinion. As the authors do not have enough space to have a full discussion on all of the opinions, they will treat investigations of close affinity to theirs.

The authors minutely investigated on the thymus in man and many kinds of animals and observed the so-called myoid cells in the medulla. Including the fowl and turtle, those cells shange into the kernel of Hassall's corpuscles (Figs. 1, 3, 11, 15). Many investigators observed those cells in man and many kinds of animals, but no one has had the same opinion with ours. The myoid cells in mammal has no myofibrils in the cell body but many filaments in it. Considering this fact, the name of the myoid cell is not suitable in case of man and mammals. The cells in the frog and snake have myofibrils, so that we may call them myoid cells.

There are many new kind of striated muscles in the medulla in the fowl, turle and soft-shelled turtle. They and the ordinary skeletal striated muscle are extremely similar (Figs. 12, 16). Those in the thymus in the turtle distinctly swell up in one part of the fibers and many nuclei are contained in this part (Figs. 13, 14). This state is exactly alike those in the intrafusal muscle fibers. The authors clearly confirmed the isotropic, anisotropic, intermediate, middle and Hensen's disks with the optical microscopy (Fig. 16). Therefore, we should treat them as a new kind of striated muscles. Jordan and Looper (1928) investigated on the thymus in the box-turtle but they did not mention anything particular on the muscles, though their " unicellular corpuscles" might probably be the swollen part of the muscle in the turtle. The same muscles in the fowl are less developed than those in the turtle, but $W$ e is se n be r g (1907) already observed the isotropic, anistropic and intermediate disks in them with the optical microscopy. Sato and $\mathrm{H}$ irose (1966) observed the middle disks in the same muscles in the fowl with the electron microscopy.

The present authors, clearly confirmed the existence of the above mentioned muscles in the center of Hassall's corpuscles in the fowl 
and the turtle (Figs. 11, 15). The authors can very frequently observe them in the fowl especially. Kra use (1921) found typical Hassall's corpuscles in the dove and Landauer (1929) in the chicken, but their reports do not contain the faintest allusion to the matter. Depending on his electron microscopy, K o k a (1960) insists that there are no myoid cells in the Hassall's corpuscles. Nevertheles, the swollen part of the striated muscles in the fowl and turtle are not always filled with the myofibrils. Some cells in a section contain the myofibrils, while the same cell in other sections has no myofibrils but only filaments.

The present authors consider that the central giant cells, namely the kernels of Hassall's corpuscles in man and mammal (Figs. 1, 3, $5,7,10)$ are the rudimental striated muscles in the fowl and turtle. Those cells compare with the swollen part of the above mentioned muscles, that is, the fibrous part had probably disappeared in the phylogenetic progress (Figs. 2,4). The authors found the giant cells with a short fiber in the medulla of the thymus in the rabbit (Fig. 8). It has not been confirmed yet whether the myofibrils in this cell exist in this animal or not. But we may regard the giant cells in the rabbit maintain the vestiges of the striated muscles in the bird and turtle. Namely, they mediate between the so-called myoid cells in man and mammal and the striated muscles in the bird and the turtle. Although, D ustin and B a ille z (1914) found the myofibrils in the so-called myoid cells in the kitten, the authors can not prove them yet in the same animal.

C l a r k $(1963,1964)$ investigated on the thymus in the young adult male mice with electron and optical microscopies, and he was positive in denying the formation of Hassall's corpuscles in this animal, but present authors did observe the same corpuscles in the adult mice. T e i c h m a n says that there are many nucleusless myoid cells, but it is his misjudgement. Namely, they are nothing but a part of the giant cells.

As the present authors have described in the observations, when the giant cells or the rudimental myoid cells in man and mammal fall into the degeneration, one reticular cell presents its crescent outlines first and contacts with the giant cell. This is the beginning of the formation of Hassall's corpuscle (Fig. 3). Gold ner (1923) and $\mathrm{K}$ a $\mathrm{m}$ i s h i m a (1951) used the term " unicellular Hassall's corpuscle" in their papers, but they did not mention what it was. The authors consider, however, they are the so-called giant cells. Namely it is the swollen part of the rudimental striated muscles. J or $d$ a $n$ and 
L o o per (1928) show the figures of the unicellular corpuscles in the box-turtle, $J$ u b a and $M$ i hál $\mathrm{i} \mathrm{k} \mathrm{(1929)} \mathrm{in} \mathrm{man} \mathrm{and} \mathrm{swine.} \mathrm{However,}$ those cells are not unicellular but they are surrounded by a few semicircular reticular cells, which are Hassall's corpuscles in the early stage. In other words, the semicircular reticular cells never come in contact with the normal central giant cells (Figs. 2, 4). K a mis h i m a (1951) found " unicellular Hassall's corpuscles" in the medulla of the thymus in the human embryo of estimated age two months at first. But the authors consider them as the central giant cells of the same corpuscles or the so-called myoid cells. The degeneration of the myoid cells in the frog and snake do not form Hassall's concentric corpuscle. In man and many kinds of animals with the exception of the above mentioned animals, the degeneration of the giant cells or particular striated muscles present the formation of the concentric Hassall's corpuscles. On the other hand, however, Mizo$\mathrm{g} \mathrm{u} \mathrm{c} \mathrm{h} \mathrm{i} \mathrm{(1930)} \mathrm{found} \mathrm{the} \mathrm{typical} \mathrm{concentric} \mathrm{Hassall's} \mathrm{corpuscles} \mathrm{which}$ were like those in mammal in the larvae of the salamander (Megalobatrachus japonicus, TEMMINCK) just after disappearance of their branchiae, but he could not recognize the same corpuscles in the adult.

The most important point in question of this study of the present authors is to clear what is the constructional element in Hassall's corpuscle. The authors consider that the same corpuscles consist of two different sorts of cells. In man and mammal the kernel of the corpuscle is only equivalent to the rudiment of the myoid cell in the frog and snake or the rudimental swollen part of a new kind of the striated muscle in the fowl and turtle. The other element of the same corpuscle is the reticular cells. Namely, Hassall's corpuscle is of such a concentric structure that the reticular cells appear around the above mentioned degenerated central giant cell. The opinion of the present authors on the structural element of Hassall's corpuscle is dualistic, while the interpretations of all other investigators ( $\mathrm{J} \mathrm{u} \mathrm{b} \mathrm{a}$ and $\mathrm{M}$ i hálik 1929, B a r g man n 1943, S m ith 1964 etc.) on the same problem are monistic. Because, according to them Hassall's corpuscles are formed by the degenerated reticular cells.

M a yer (1888), S c haf fer (1893), B o l a u (1899), P e n s a (1902, 1904), $\mathrm{H}$ a m mar (1905), $\mathrm{K}$ r a u s e (1931), T e i c h m a n (1942) etc. observed the reticular cells containing striated myofibrils in the cytoplasm, and $\mathrm{H}$ a $\mathrm{m} \mathrm{m}$ a $\mathrm{r}$ named them myoid cells. $\mathrm{H}$ a $\mathrm{m}$ m a $\mathrm{r}$ considers the myoid cells are originated in the endodermal reticular cells, and $\mathrm{B}$ a $\mathrm{g} \mathrm{m}$ a $\mathrm{n} \mathrm{n}$ (1943) also interprets the hypertrophied reticular cell with fibrils as the unicellular Hassall's corpuscle. Although the 
authors investigated on the myoid cells and Hassall's corpuscles in the rabbit embryos, both of them were not seen in the two individuals of estimated age twenty-five. But nearly round and large cells containing round and large nucleus and filaments in the cytoplasm, lightly stained with eosin, were observed in the two one-day-old individuals (Fig. 9). They are the so-called myoid cells, and the typical Hassall's corpuscles are also observable in those materials, and the same myoid cell is contained in the center of the corpuscle.

The authors insist that the rudimental myoid cells in man and mammal, myoid cells in the frog and snake and a new kind of striated muscles in the fowl and turtle are of the same sort, and they are all originated in the endodermal epithelial cells. The possibility of the transformation of the reticular cells into the myoid cells or striated muscle is not conceivable. Because we should regard that the muscles, myoid cells and reticular cells are already differentiated into the different directions. The large cells in the tissue culture of the rabbit which is executed by $\mathrm{Sch}$ op per bear a striking resemblance to the above mentioned central giant cells in the same animal used by the authors. It seems to be proper to say that Schopper's preparation (cited from Barg m a n n's Abb. 49) thoroughly supports our insistence.

On the significance of the formation of Hassall's corpuscle is as follows. The epithelial cells of the primordium of the thymus differentiate into two kinds of cells. One is the reticular cell and the other is myoid cell or striated muscle. These cells or muscles are destined to degenerate. To remove these degenerated cells or muscles, the neighboring reticular cells appear around them. They acquire the phagocytic character to clear the degenerated substances. Due to a large quantity of the degenerated substances, those reticulum cells also get degenerated. Then new phagocytic reticular cells appear again around the degenerated reticular cells. In this way the concentric arrangement of the degenerated reticular cells is formed. But if the reticular cells go far from the center of the corpuscle, the degenerated substance reduce in quantity. Thus the formation of Hassall's corpuscle ceases. As the result the same corpuscle consists of at most about four to five layers. If two or more degenerated myoid cells near close to each other, the polynuclear Hassall's corpuscle comes into existence.

The degeneration of the myoid cells in the frog and snake does not form the concentric Hassall's corpuscles. This may be caused by the functional differences of those reticulum cells. 
It is to be mentioned here that the authors can not decide yet whether the reticular cells which participate in the formation of the concentric layers of Hassall's corpuscle are endodermal or mesenchymal. Basing upon the tissue culture of the rabbit thymus of $\mathrm{S} c \mathrm{~h}$ op per (1934), B a r g m a n n denies the contention of We is e's (1940) that the concentric corpuscles in the thymus are originated from the "degenerated primitive corpuscles". The authors can presume that the same cells are the so-called rudimental myoid cells, and that B a r g$\mathrm{m}$ a $\mathrm{n} \mathrm{n}$ figure (Abb. 50) of the tissue culture indisputably shows the true concentric Hassall's corpuscle. The mechanism of the formation of the same corpuscle in vitro seems to be the same as in vivo. It is to be noted that the authors have not obtained any new view on this study by the electron microscopy.

\section{Summary}

The present authors investigated on the thymus in man and many kinds of animals and obtained the following results.

1. The kernel in Hassall's corpuscle is the rudimental myoid cell in man and mammal, and a new kind of skeletal striated muscle in the fowl and turtle.

2. The giant cells in the medulla of the thymus in man and mammal are the rudimental myoid cells.

3. The fibrous part of the muscle in the medulla of the thymus in the fowl and turtle is quite similar to the ordinary skeletal striated muscle, and we can easily find the clear isotropic, anisotropic, intermediate, middle and Hensen's disks in the turtle with the optical microscopy. These muscles have a swollen part and contain many nuclei in it, and are similar to the intrafusal muscle fibers. But the authors consider that this is a new kind of striated muscle. The above mentioned disks are not so clear and do not contain so many nuclei in the swollen part in the fowl.

4. The rudimental myoid cells in man and mammal are the rudiment of the striated muscles in the fowl and turtle.

5. The striated, the rudimental myoid cells and the reticular cells in the medulla are all originated in the epithelium of the primordium of the thymus. The muscles or myoid cells and the reticular cells differentiate into several different directions, so the authors can not consider the possibility of the transformation of the reticular cells into the myoid cells or muscles.

6. The myoid cells in the frog and snake have myofibrils in the 
cell body, but those in man and mammal have none. Therefore, the "myoid cell" is not adequate to man and mammal.

7. One swollen part of the striated muscle in the fowl and turtle contains concentric myofibrils, while in the other section of the same part has no fibrils but contains many filaments.

8. The above mentioned giant cells, namely, rudimental myoid cells or muscles in the medulla of the thymus are destined to degenerate, and the phagocytic reticular cells appear around them to get rid of the degenerated cells. Those reticular cells also degenerate as the result after taking in the injurious substance of the degenerated kernel cells. After degeneration of those reticular cells, other phagocytic cells appear adjacent to them. Thus the formation of the concentric structure goes on. Therefore, the authors are for the dualism on the constitution of Hassall's corpuscles, while all the other investigators are for the monism.

9. The phagocytic reticular cells far from the center of the corpuscles take in a small quantity of the degenerated injurious substance. So that the cells do not extinguish in such a position and the formation of Hassall's corpuscles stops.

10. The normal rudimental myoid cells in man and mammal never accompany the reticular cells around them. The unicellular Hassall's corpuscles of the previous investigators are probably equivalent to the above mentioned rudimental myoid cells or Hassall's corpuscles in early stage.

11. The degenerated myoid cells in the frog and snake do not form the concentric Hassall's corpuscles. This may be caused by the different function of their reticulum cells.

\section{References}

A f a n a s siew, B. 1877. Über die Konzentrischen Körper des Thymus. Arch. f. mik. Anat. 14: 1-7.

*A f a $\mathrm{n}$ a s s i e w, B. 1877. Weitere Untersuchungen über den Bau und die Entwicklung der Thymus und der Winterschlafdrüse der Säugetiere. Arch. mik. Anat. 14, 343390.

A m ma n, A. 1882. Beiträge zur Anatomie der Thymusdrüse. Diss. Basel. (cited from $\mathrm{Ha} \mathrm{m} \mathrm{mar}$ )

Arnold, 1831. (cited from Juba and v. Mihálik)

B a r g m a n n, W. 1943. Der Thymus, Möllendorff's Handb. d. mik. Anat. d. Menschen, VI, TI. $4: 1-172$.

B arker, D. and Cope, M. 1962. The Innervation of Individual Intrafusal Muscle Fibres. Symposium on muscle receptors, 263-269.

*B e a r d, J. 1902. The origin and histogenesis of the thymus in Raja batis. Zool. Jb., 
Anat. u. Ontog. 17.

* $\mathrm{B}$ é clè r e, H. et $\mathrm{P}$ i $\mathrm{g}$ a $\mathrm{ch}$ e, $\mathrm{R}$. 1911. Action des rayons de Roentgen sur les corpuscules de Hassall. Bull. Soc. Anat. Paris, 86: 47-51.

*B e 11, E. T. 1906. The development of the thymus. Amer. J. Anat. 5: 29-62.

*B o 1 a u, H. 1899. Glandula thyreoidea und Glandula thymus der Amphibien. Zool. Jb., Anat. u. Ontog. 12

B ruch, 1855 (cited from Juba and v. Mihálik)

*Ca pobia n co, F. 1890. Della natura dei corpuscoli di Hassall contribuzione alle conoscenze morphologische del timo. Boll. Soc. Natur. Napoli I. s., 4.

Clark, S. L. 1963. The thymus in mice of strain $129 / \mathrm{J}$, studied with the electron microscope. Am. J. Anat., 112: 1-3.

Cla r k, S. L. Jr. 1964. Electron Microscopy of the Thymus in Mice of Strain 129/J, The Thymus in Immunobiology, 85-94.

Cornil et Ranvier, 1869. Manuel d'histologie pathologique. Paris. (cited from $\mathrm{H}$ a m mar)

Dah m s, 1877. (cited from Juba and v. Mihálik)

De a r h, O.A. 1928. Late development of the thymus in the cat: Nature and significance of the corpuscles of Hassall and cystic formations. Am. J. Anat., 41: 321-351.

*D u stin, A.P. 1908. L'origine et la signification des cellules „myoides" et "épithéloides" du thymus. Ann. Soc. roy. Sci. méd. et natur. Brux, 1908.

*Dust in et Baille $z, 1914$. Sur l'existence de cellules myoides dans le thymus des mammifères. Ann. Soc. roy. Sci. méd. et natur. Brux, 123-125.

*E bner, V.v. 1902 . Von der Thymus. A Koellikers Handbuch der Gewebelehre, 6. Aufl., 328-340.

*Friedle be n, A. 1858. Die Physiologie der Thymusdrüse in Gesundheit und Krankheit. Frankfurt. a. M.

*Fu lci, F. 1913. Die Natur der Thymusdrüse nach Untersuchungen über ihre Regeneretionsfähigkeit bei den Säugetieren. Dtsch. med. Wschr. II, 1776-1780.

G hik a, Ch. 1901. Étude sur le thymus. Thèse de Paris. (cited from $\mathrm{H} \mathrm{a} \mathrm{m} \mathrm{ma} \mathrm{r)}$

${ }^{*} \mathrm{G}$ o $1 \mathrm{~d} \mathrm{n}$ e r, J. 1923. Histogénèse du corpuscule de Hassall; Unité cytogénique des cellules de charpente, des placards épithéliau des corpuscules unicellaires et des corpuscules Hassalliens. C. r. Soc. Biol. Paris, 88: 947-950.

Gont scharukow, 1895. (cited from Juba and v. Mihálik)

*Gooda11, A. 1905. The Postnatal changes in the thymus of guinea pigs and the effect of castration on thymus structure. J. of physiol., 32: 191-198.

*G r é g o i r e, Ch. 1932.

Gurwits ch. 1907. (cited from Juba and v. Mihálik)

H a m ma r, J.A. 1905. Zur Histologie und Involution der Thymusdrüse. Anat. Anz., $27: 23-30$.

H a $m \mathrm{~m}$ a r, J. A. 1905. Zur Histogenese und Involution der Thymusdrüse. Anat. Anz., $27: 41-89$.

${ }^{*} \mathrm{H}$ a m m a r, J. A. 1909. Fünfzig Jahre Thymusforschung. Erg. Anat., 19: 1-274.

Hertwig, O. 1890. (cited from J u ba and v. Mihá $1 \mathrm{ik}$ )

$\mathrm{H}$ i s, W. 1880. Anatomie menschlicher Embryonen, Leipzig. (cited from $\mathrm{H} \mathrm{a} \mathrm{m} \mathrm{m} \mathrm{a} \mathrm{r)}$

* J a f f e, H.L. and Plavska, A. 1925. Experimental studies on the formation of Hassall's corpuscles. Proc. Soc. Exper. Biol. a. Med., 23 : 91-93.

Jolly and Levin, 1910. (cited from Juba and v. Mihálik)

*J or da n, H. E. and Horsle y, G.W. 1927. Significance of concentric corpuscles of Hassall. Anat. Rec., 35 : 279-303. 
Jordan, H.E. and Looper, J.B. 1928. The histology of the thymus gland of the box-turtle, Terrapene carolina, with special reference to the concentric corpuscles of Hassall and the eosinophilic granulocytes. Anat. Rec., $40: 309-337$.

J u ba, A. und M ihálik, P.v. 1929. Über die Entstehung der Hassalschen Körperchen. Zeitschr. f. Anat. u. Entwickl., $90: 278-287$.

K a m is h i ma, T. 1951. Studies on the Hassall's corpuscles (1). Jap. Jour. Leg. Med., $5: 302$.

Ka s a rinow, 1899. (cited from J u ba and v. Mihálik)

Koelliker, A. 1879. Entwicklungsgeschichte 2. Aufl. Leipzig. (cited from $\mathrm{H}$ a m$\mathrm{mar}$ )

Kok a, T. 1960. Electron Microscopic Studies on the Thymus, Especially on Epithelial cell. Acta Medica, 30: 91-107 (in Japanese).

*Kost o w i e cki, M. 1930. Über die Beziehung der Hassallschen Körperchen zu den benachbarten Blutgefässen in der Thymus menschlicher Feten. Bull. internat. Acad. polon. Sci. Cracovie.

$\mathrm{Kr}$ a u se, 1876. (cited from $\mathrm{J} \mathrm{uba}$ and v. Mihá $\mathrm{lik}$ )

*K r a u s e, 1921. S., $63: 71$.

*L a n d a u e r, W. 1929. Untersuchungen über Chondrodystrophie. III. Die Histologie der Drüsen mit innerer Sekretion von chondrodystrophischen Hühnerembryonen. Virchows Arch., 271 : 534-545.

Letulle und $\mathrm{Nat}$ a n-Larrier, 1902. (cited from Juba and v. Mihálik)

*L e y d i g, Fr. 1857. Lehrbuch der Histologie des Menschen und der Tiere. Frankfurt a. $\mathrm{M}$.

*M a g n i, S. 1903. Über einige histologische Untersuchungen der normalen Thymusdrüsen eines fünfmonatlichen und eines reifen Fetus. Arch. Kinderheilk., 38 : 14-17.

*Marin e, D. 1915. The frequency of ductlike spaces in the thymus gland, with remarks on the formation and fate of Hassall's corpuscles. Cleveland med. J., 14 : 186-195.

*M a s s a r t, C. 1940 .

M a u re r, F. 1886. Schilddrüse und Thymus der Teleostier. Morph. Jahrb., 11: 129175.

*M a u r e r, F. 1899. Die Schilddrüse, Thymus und andere Schlundspaltenderivate bei der Eidechse. Morph. Jb., $27:$ 119-172.

${ }^{*} \mathrm{M}$ a $\mathrm{x}$ i m ow, A. 1909. Untersuchungen über Blut und Bindegewebe. II. Über die Histogenese der Thymus bei Säugetieren. Arch. mik. Anat., $74: 525-621$.

*M a y e r, S. 1888. Zur Lehre von der Schilddrüse und Thymus bei den Amphibien. Anat. Anz., 3 : 97-103.

${ }^{*} \mathrm{M}$ i e ten s, H. 1908. Zur Kenntnis des Thymusretikulum und seiner Beziehungen zu dem der Lymphdrüsen, nebst einigen Bemerkungen über die Winterschlafdrüse. Jena Z. Naturwiss., $44: 149-192$.

M i z o g u chi, T. 1930. The development of the thymus. Acta Anat. Nipp., 3: 383449. (in Japanese)

$\mathrm{Nusb}$ a u m, J. und Pry mak, Th. 1901. Zur Entwicklungsgeschichte der lymphoiden Elemente der Thymus bei den Knochenfischen. Anat. Anz., 19. (cited from $\mathrm{H}$ a $\mathrm{m} \mathrm{mar}$ )

$\mathrm{Nusbaum}$, J. und Machow ski, J. 1902. Die Bildung der concentrischen Körperchen und die phagocytotischen Vorgänge bei der Involution der Amphibienthymus nebst einigen Bemerkungen über die Kiemenreste und Epithelkörper der Amphibien. Anat. Anz., $21:$ 110-127. 
O k a m u r o, T. 1928. On the relation between the Hassall's corpuscles and the branchial canal. Kyoto Fur. Ikadaigaku Zasshi, 2 : 305-320. (in Japanese)

Orth, 1888. (cited from Juba and v. Mihálik)

*P a u lit z ky, A. 1863. Disquisitiones de stratis glandulae thymi corpusculis. Halis.

* P e n s a, A. 1902 . Osservazione a proposito di una particolarità di struttura del timo (nota preventiva). Boll. Soc. med.-chir. Pavia.

* Pen s a, A. 1904. Ancora a proposito di una particolarità di struttura del timo ed osservazioni sullo sviluppo del timo negli Anfibi Anuri. Boll. Soc. med.-chir. Pavia.

*Pf 1 ü cke, M. 1906. Die Thymus. Handbuch der vergleichenden mikroskopischen Anatomie der Haustiere, herausgeg. von Ellenberger.

Pier s ol, 1909. (cited from J u ba and v. Mihálik)

*P i g a c h e, R. et W or m s, G. 1912. Le thymus considéré comme gland à sécrétion interne. C. r. Acad. Sci. Paris, $154: 234-236$.

*P o p of $f, 1927$.

*Pren a n t, A. 1894. Contribution a l'étude organique et histologique du thymus, de la glande thyroide et de la glande carotidienne. Cellule 10.

Pry mak and Dustin, 1909. (cited from Juba and v. Mihá 1 i k)

*R e g a u d, C. et Crémi e u, 1911. Evolution des corpuscules de Hassall dans le thymus röntgénisé du chat. 1. Méchanisme de l'accroissement de ces corpuscules. C. r. Soc. Biol. Paris, $71: 325-326$.

Ren a ut, 1897. (cited from $\mathrm{Juba}$ and v. Mi há $\mathrm{lik}$ )

Sato, M. and Hirose, T. 1966. Fine Structure of the Myoid Cell in the Thymus of the Domestic Fowls. Acta. Med. Univ. Kagoshima, Vol. 8, Num. 2, 137-140.

* Sc h a f f er, J. 1893. Über den feineren Bau der Thymus und deren Beziehung zur Blutbildung. Sitzgsber. Akad. Wiss. Wien. Math.-naturwiss. K1. III, 102.

*S c h a m b a c her, A. 1903. Über die Persistenz von Drüsenkanälchen in der Thymus und ihre Beziehung zur Entstehung der Hassallschen Körperchen. Virchows Arch., 17.2 : 368-394.

*Sch o p per, W. 1934. Thymusgewebe in der Kultur mit vergleichenden kinematographischen Aufnahmen von Thymus- und Milzkulturen. Zbl. Path. 60, Erg.-H. 216-221, 226-233.

Smith, C. 1964. The Microscopic Anatomy of the Thymus. The Thymus in Immunobiology, 71-84.

*S t i e d a, L. 1881. Untersuchungen über die Entwicklung der Glandula thymus, Glandula thyreoidea und Glandula carotica. Leipzig.

*S tö h r, Ph. sen. 1906. Über die Natur der kleinen Thymuszellen. Anat. H., 31: 409457.

Sz y monovic $z, 1901$. (cited from J u ba and v. Mihálik)

Tartozzi, 1906. (cited from Juba and v. Mihálik)

* T e i c h m a n n, W. 1942. Über die myoiden Zellen des Thymus. (Untersuchungen am Thymus von Schlangen) Z. Zellforsch., $32:$ 194-208.

Tobari, K. 1938. Über die Entwicklung der Thymuszellen beim Hühnerembryo. Acta Anat. Nipp., $11: 534-561$ (in Japanese).

Toldt, 1877. (cited from Juba and v. Mihálik)

T ourne ux, 1909. (cited from Juba and v. Mihálik)

* T s chas sow nikow, N. 1926. Über in vitro-Kulturen der Thymus. Arch. exper. Zellforsch., $3: 250-276$.

*W a t $n$ e $y, 1878$. Note on the minute anatomy of the thymus. Proc. Soc. roy. Soc. 27. 
*W a tn e y, H. 1882. The minute anatomy of the thymus. Phil. Trans. roy. Soc. Lond. 1063-1123.

*W a t n e y, H. 1882. The minute anatomy of the thymus. Phil. Trans. roy. Soc. Lond. 3.

*W e ise, W. 1940. Morphologie und Klinik des Thymus. Dtsch. Z. Chir., 253 : 145-236.

*W e is se n berg, R. 1907. Über die quergestreiften Zellen der Thymus. Arch. mik. Anat., 70 : 113-226.

*W in i w a r t e r, H. de. 1923. Origine des corps de Hassall du thymus des mammifères (chien et chat). C. r. Soc. Biol. Paris, 89: 834-836.

(*: cited from Bargmann) 


\section{Explanation of Figures}

\section{Plate I}

1. One normal rudimental myoid cell (1) and one small Hassall's corpuscle (2) in man, stained with hematoxylin-eosin, $\times 550$.

2. A few normal rudimental myoid cells $(\uparrow)$ in the dog, stained with hematoxylin-eosin, $\times 550$.

3. Hassall's corpuscle of early stage in puppy ( $\uparrow)$. Three semicircular nuclei of the reticulum cells surrounding the degenerated rudimental cells, stained with hematoxylin-eosin. $\times 330$.

4. A few normal rudimental myoid cells $(\uparrow)$ in the calf, stained with hematoxylin-eosin. $\times 550$.

5. Two Hassall's corpuscles of very early stage in the cattle ( $\uparrow$ ). Many droplets stained with hematoxylin are seen in the cytoplasm. Hematoxylin-eosin stain. $\times 550$.

6. A large Hassall's corpuscle containing three nuclei in the cattle. The rudimental myoid cell lies in the right corner $(\uparrow)$. We can recognize remarkable decrease of DNA in the kernel of the corpuscle by Feulgen reaction. Cytoplasm is darkly stained with light green. $\times 550$.

7. A few normal rudimental myoid cells (1) and one old Hassall's corpuscle (2) in the rabbit, stained with hematoxylin-eosin. $\times 550$.

8. Two rudimental myoid cells with the fibrous process in the rabbit ( $\uparrow)$, stained with Pasini's method. $\times 900$. 


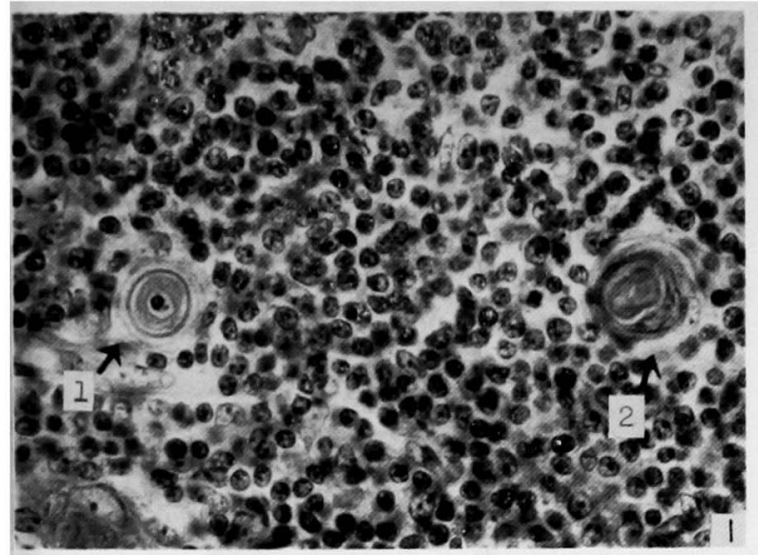

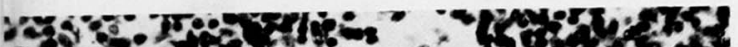

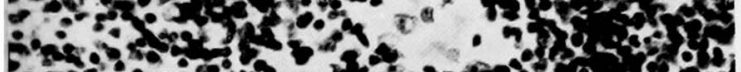

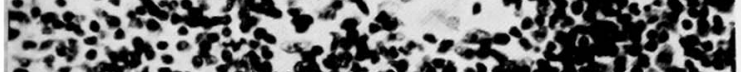
of

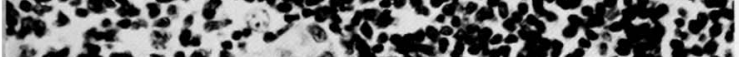

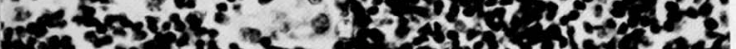

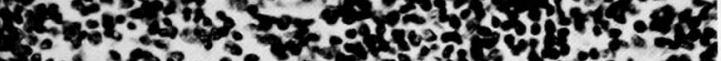

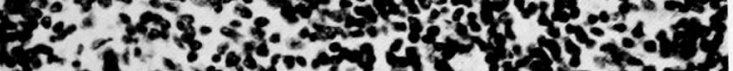
con ${ }^{2}$.

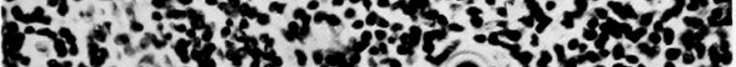

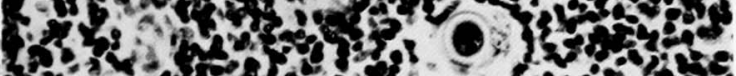

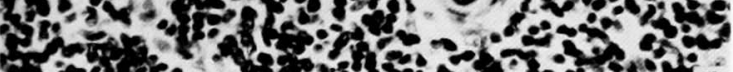

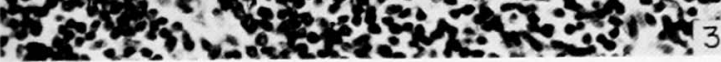

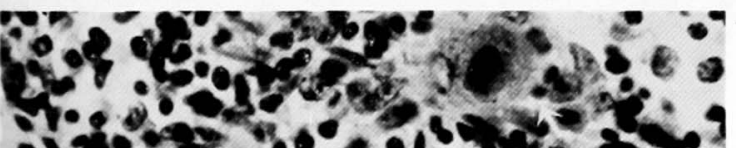

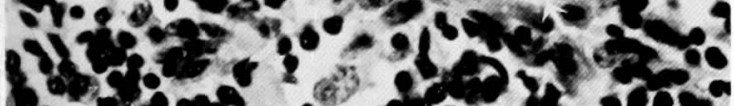

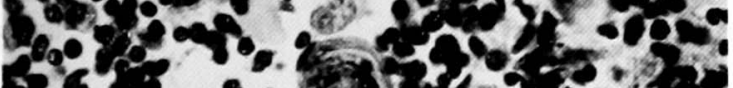

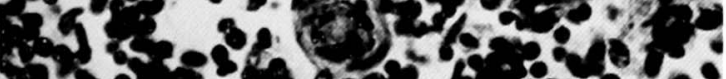
me di a a 2.t

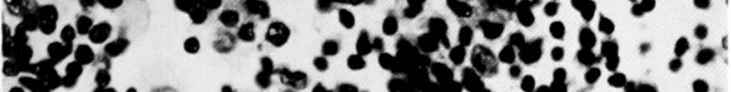

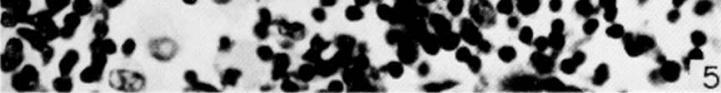

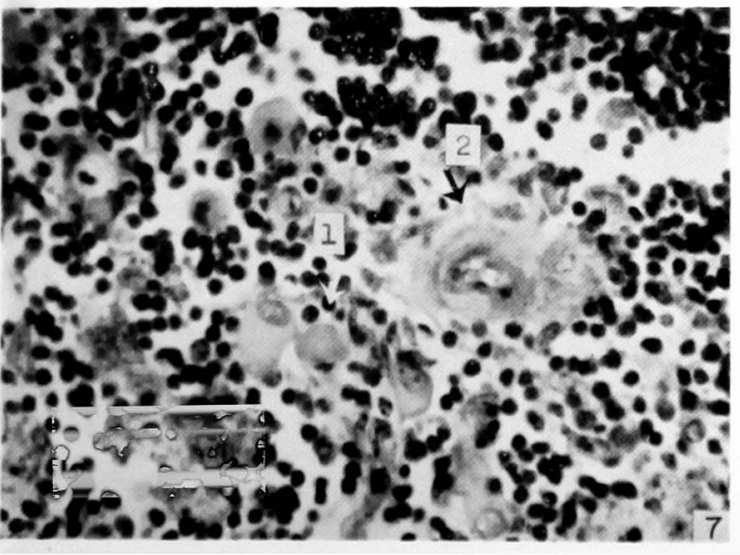

-8

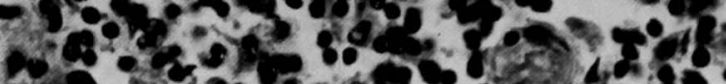

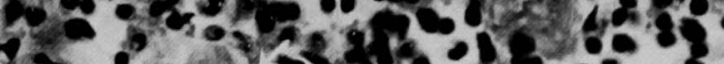

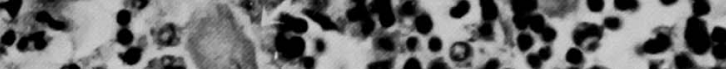

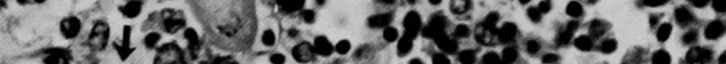

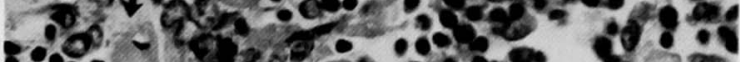

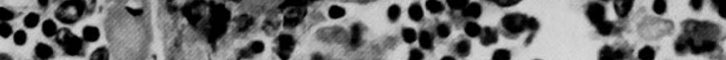

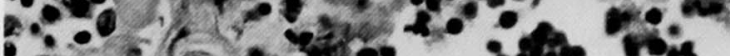

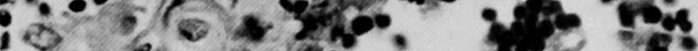

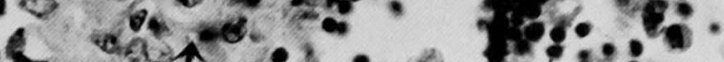

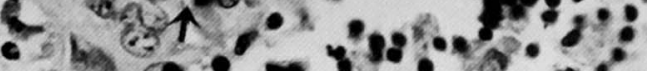

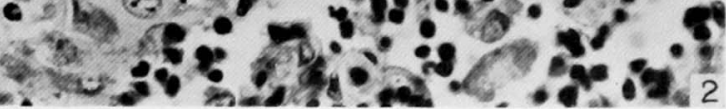

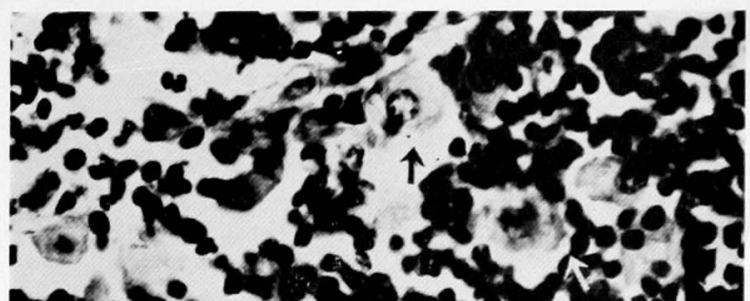

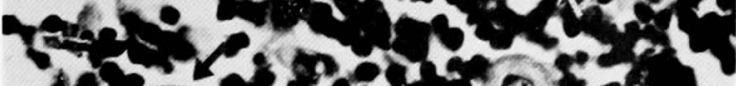

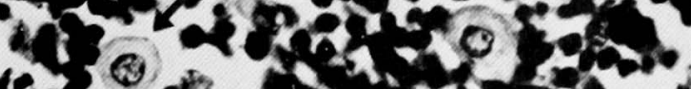
is

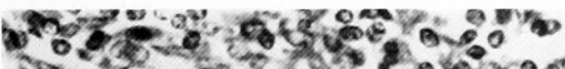

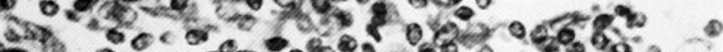
- का $0^{\circ}$ \% 000 .

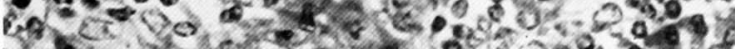
(x)

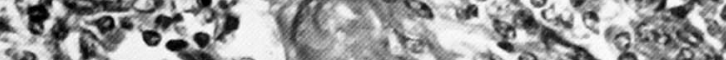

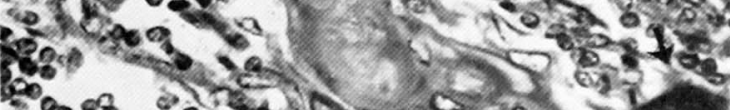

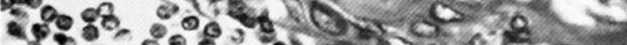

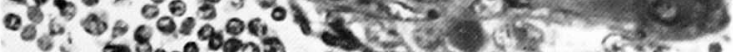

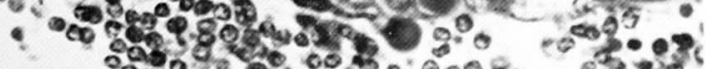

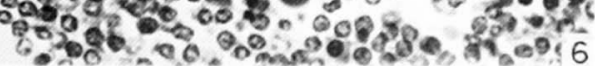

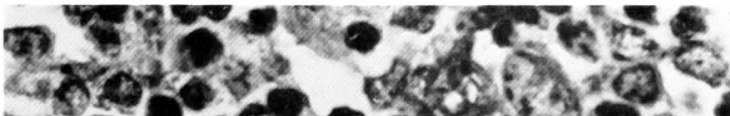

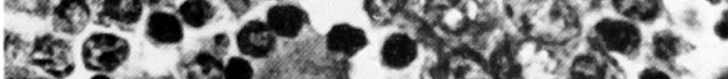
\% E

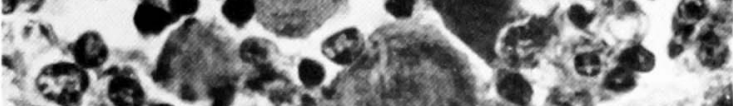

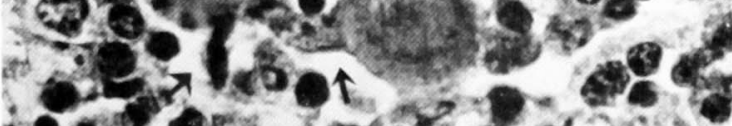

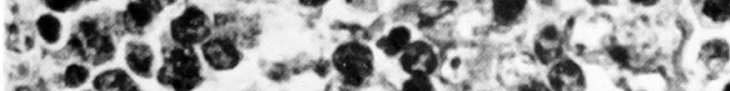

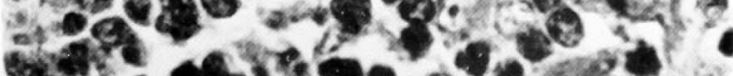

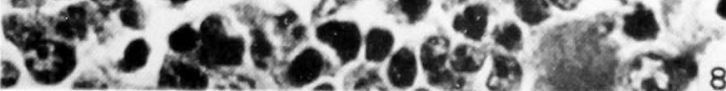




\section{Explanation of Figures}

\section{Plate II}

9. Rudimental myoid cell $(\uparrow)$ in the twelve-day-old rabbit, stained with hematoxylin. eosin. $\times 550$.

10. Hassall's corpuscle in the puppy, stained with Unna-Pappenheim's method. DNA and RNA in the myoid cell and the reticulum cells around it $(\uparrow)$ are remarkably less than those of the thymocytes and etc. $\times 330$.

11. Hassall's corpuscle of early stage $(\uparrow)$ in the nine-day-old chicken. The swollen part of the striated muscle surrounded by a few reticulum cells, stained with hematoxylin-eosin. $\times 550$.

12. Striated muscles in the medulla of the thymus in the Japanese terrapin (Clemmys japonica, TEMmincK et SCHLEgel). The swollen part invisible, stained with hematoxylin-eosin. $\times 550$.

13. Striated muscle with a swollen part in the medulla of the thymus in the Japanese terrapin. One transverse section of the swollen part containing no nucleus $(\uparrow)$, stained with hematoxylin-eosin. $\times 550$.

14. Transverse sections of the swollen part of the striated muscles in the medulla of the thymus in the Japanese terrapin. One of them with six nuclei in it, stained with hematoxylin-eosin. $\times 1,000$.

15. A few transverse sections of the swollen parts of the striated muscles in the medulla of the thymus in the Japanese terrapin. One of them being in contact with a reticular cell $(\uparrow)$; the beginning of the formation of concentric Hassall's corpuscle, stained with hematoxylin-eosin. $\times 900$.

16. The striated muscles in the medulla of the thymus in the Geoclemys reevesii (GRAY). The intermediate (1) and middle disks (2) clearly visible, stained with Unna's water blue-orcein-eosin. $\times 1,200$. 


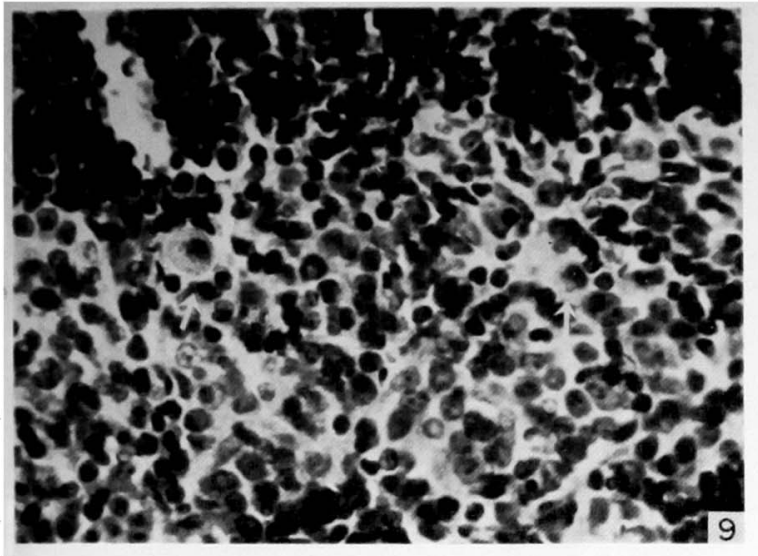

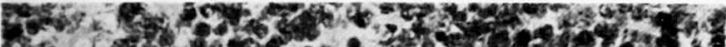

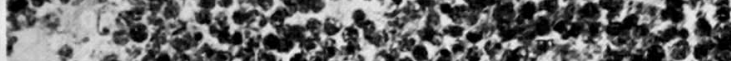
4 ons

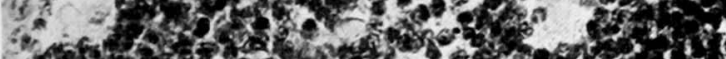

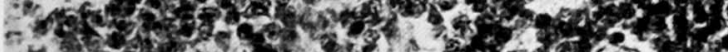

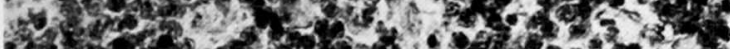

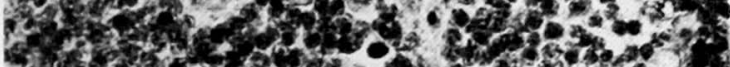
5.

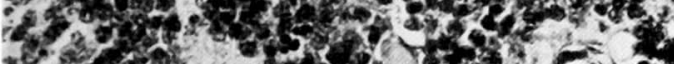

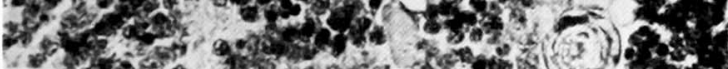

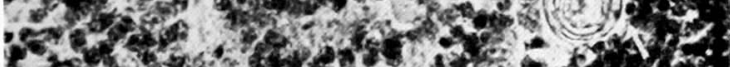
7.n.

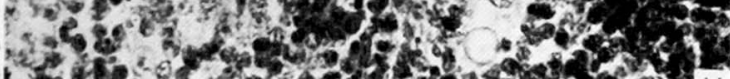

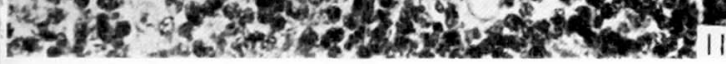

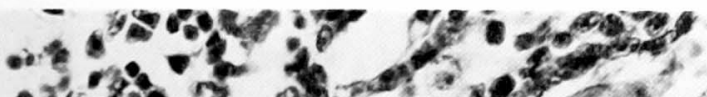

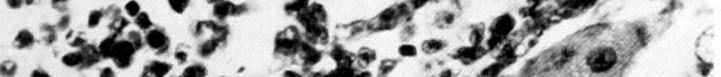

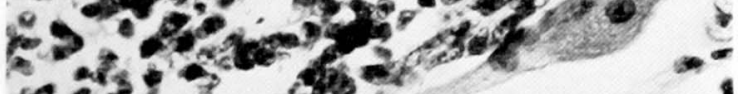
$103^{3}-300$

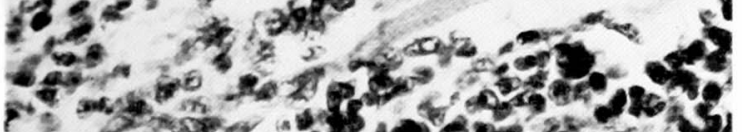

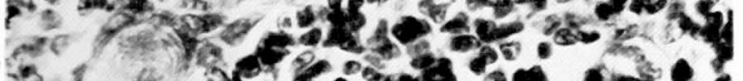

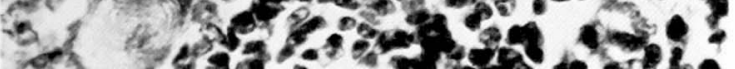

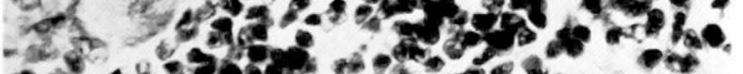

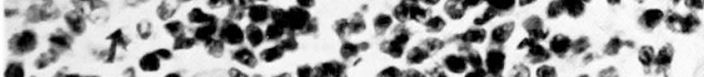

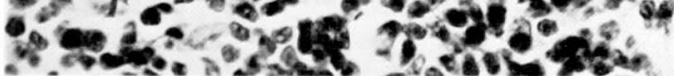

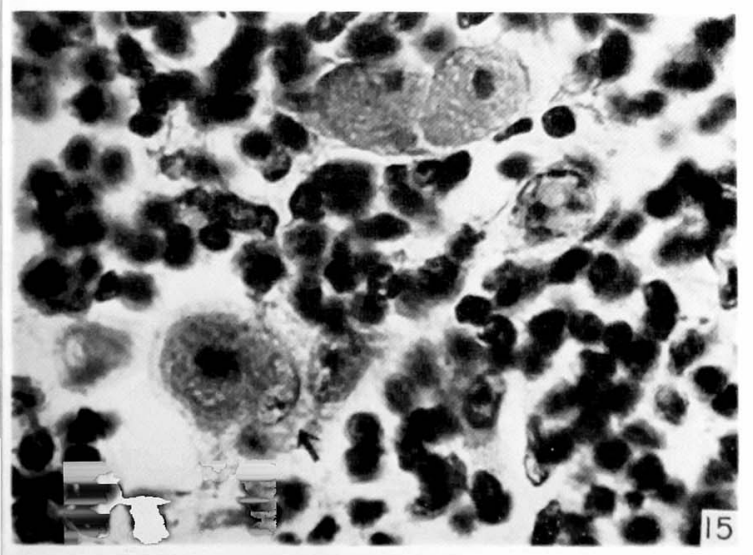

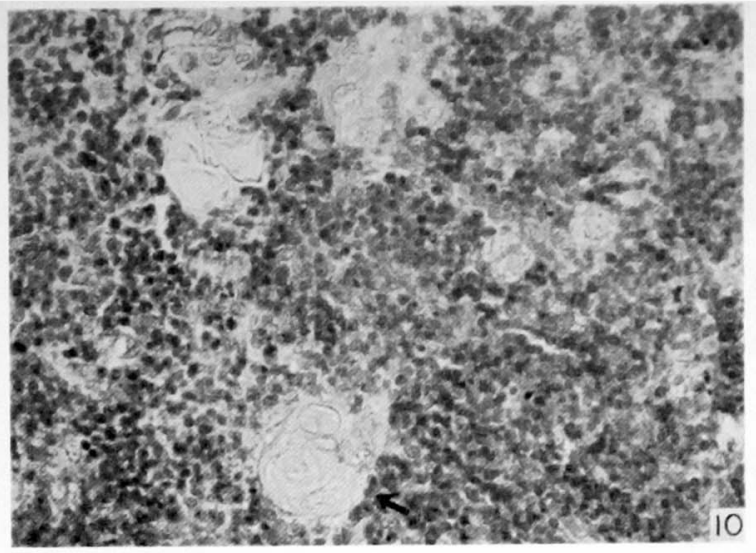

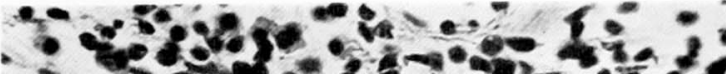

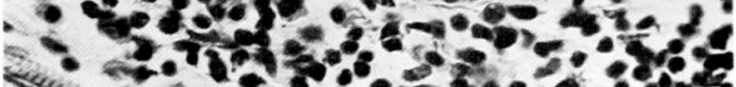

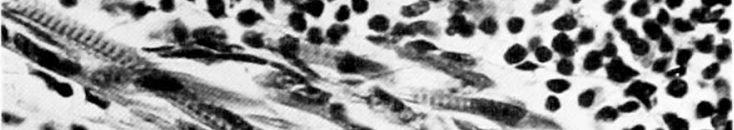

$-10 \mathrm{~s}$ -

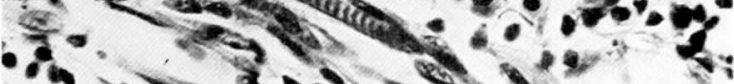

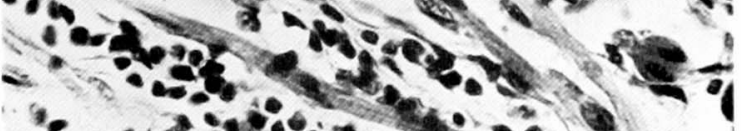

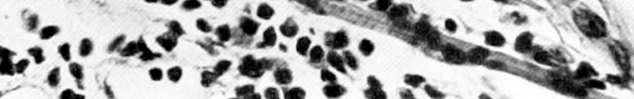

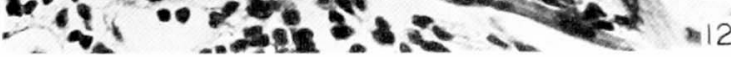
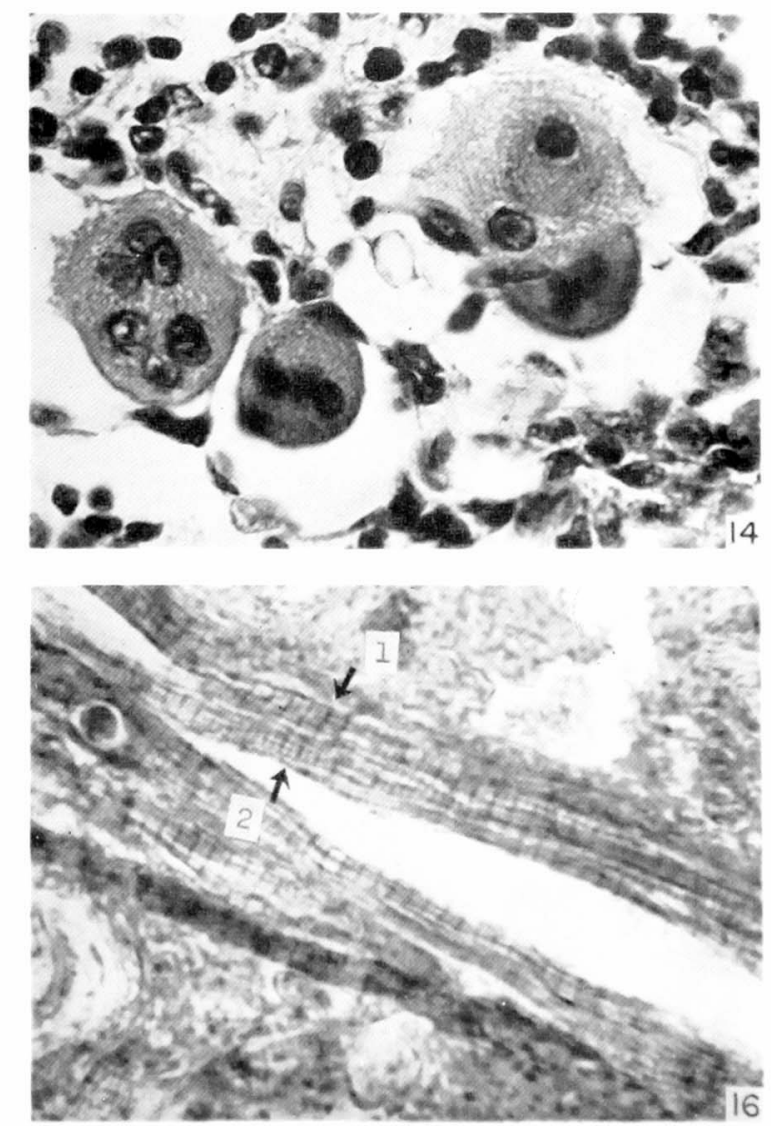